\section{Growth and Flowering Response of Butterfly-bush to Paclobutrazol Formulation and Rate of Application}

\author{
John M. Ruter ${ }^{1}$ \\ Department of Horticulture, University of Georgia, Coastal Plain \\ Experiment Station, Tifton, GA 31793
}

Additional index words. Buddleia davidii, growth retardant, growth inhibitor, PP333

Vigorous shoot growth and poor root development are problems associated with container production of butterfly-bush (Buddleia davidii Franch. 'Dubonnet'), necessitating multiple prunings during production to produce a marketable plant.

Paclobutrazol $\{\beta$-[4-chlorophenyl)methyl]$\alpha$-(1,1-dimethylethyl)-1H-1,2,4-triazole-

1-ethanol\} is known to retard growth of woody landscape plants (Keever et al., 1990) and enhance flowering (Bailey et al., 1986; Keever et al., 1990; Wilkinson and Richards, 1991). The purpose of this investigation was to study the effect of paclobutrazol formulation and rate of application on the growth and flowering response of butterflybush.

Seventy-two plants were grown in 2.8-bter pots and pruned to a height of $17 \mathrm{~cm}$ on

Received for publication 17 Dec. 1991. Accepted for publication 4 May 1992. Research conducted at Wight Nurseries, Cairo, Ga. The technical assistance of Bruce Tucker and David Walker and statistical assistance of Ben Mullinix is greatly appreciated. I appreciate the gift of paclobutrazol from ICI Americas. Supported by state and Hatch funds allocated to the Georgia Agricultural Experiment Station. The cost of publishing this paper was defrayed in part by the payment of page charges. Under postal regulations, this paper therefore must be hereby marked advertisement solely to indicate this fact.

'Assistant Professor.
26 June 1991. The potting medium consisted of 4 pine bark : 1 sand $(\mathrm{v} / \mathrm{v})$. Liquid fertilizer (10N-1.5P-8.5K) was applied with each irrigation at $100 \mathrm{mg} \mathrm{N} /$ liter. Plants were grown in full sun and irrigated as needed at $20 \mathrm{~mm} /$ irrigation using overhead sprinklers.

Paclobutrazol $[(0,5,10,20$, or $40 \mathrm{mg}$ a.i./ pot) ICI Americas, Richmond, Calif.] was applied to the surface of the container medium as a granular formulation $(2.5 \% \mathrm{RG})$ or as a single 100-ml liquid drench (Clipper $2 \mathrm{SC}$ ) on 28 June 1991. The experiment was terminated 12 Aug. 1991, because control plants required further pruning to remain marketable. Measurements at the termination of the study included growth index [(height + width1 + width2)/3], height, root dry weight, shoot dry weight, panicle count, panicles with open florets, and panicle length. The design was completely randomized, with eight replicate plants per treatment. Data were evaluated by analysis of variance and regression analysis where appropriate (SAS Institute, Gary, N.C.).

Paclobutrazol formulation influenced all plant characteristics recorded; rate of application influenced all but the number of panicles, but the interaction was significant only for root dry weight (Table 1). Growth index was reduced $50 \%$ by granular paclobutrazol at $10 \mathrm{mg}$ a.i./pot; as a liquid drench, $20 \mathrm{mg}$ a.i./pot was required to achieve an equivalent reduction.

Granular and liquid paclobutrazol reduced shoot dry weight proportional to the rate of application (Table 1). Root dry weight was reduced to the greatest degree at $20 \mathrm{mg}$ a.i./ pot for both formulations. The greater response of shoot vs. root dry weight translated into higher root : shoot ratios among paclobutrazol-treated plants. Total plant biomass (averaged across rate) was reduced $\approx 40 \%$ and $33 \%$, respectively, for the granular and liquid formulations of paclobutrazol compared to the control.

Granular paclobutrazol reduced the panicle count per plant, while the liquid formulation had no effect (Table 1). Panicle length (averaged across rate) was reduced more by the granular formulation $(66 \%)$ than by the liquid formulation (40\%) when compared with the control. Formulation and rate of application had no effect on the number of panicles with open florets (data not presented).

Growth suppression on other woody landscape plants was greater when paclobutrazol was applied as a drench than as a foliar spray (Keever et al., 1990). In this study, granular paclobutrazol reduced growth and flowering to a greater degree than liquid drenches. Granular paclobutrazol at rates $>5 \mathrm{mg}$ a.i./ pot produced butterfly-bush plants too small to be marketable. A 10-mg a.i./pot drench of liquid paclobutrazol produced a quality, marketable plant. At this rate, liquid paclobutrazol reduced the growth index and plant biomass by $\approx 33 \%$. Thus, appropriate application of paclobutrazol could be used successfully to control the growth of butteffybush.

\section{Literature Cited}

Bailey, D.A., T.C. Weiler, and T.I. Kirk. 1986. Chemical stimulation of floral initiation in florists hydrangea. HortScience 21:555-257.

Keever, G.J., W.J. Foster, and J.C. Stephenson. 1990. Paclobutraxol inhibits growth of woody landscape plants. J. Environ. Hort. 84:41-47.

WiIkinson, R.I. and D. Richards. 1991. Influence of paclobutrazol on growth and flowering of Rhododendron 'Sir Robert Peel'. HortScience 26:282-284.

Table 1. Influence of paclpobutrazol formulation (granular or liquid) and rate of application on growth and flowering characteristics of butterfly-bush.

\begin{tabular}{|c|c|c|c|c|c|c|c|c|}
\hline Formulation & $\begin{array}{c}\text { Rate } \\
\text { (mg a.i./pot) }\end{array}$ & $\begin{array}{l}\text { Growth } \\
\text { index }\end{array}$ & $\begin{array}{c}\text { Root dry wt } \\
\text { (g) }\end{array}$ & $\begin{array}{l}\text { Shoot dry wt } \\
\text { (g) }\end{array}$ & $\begin{array}{l}\text { Root : shoot } \\
\text { ratioy }^{y}\end{array}$ & $\begin{array}{c}\text { Plant } \\
\text { biomass }^{x}\end{array}$ & No. panicles & $\begin{array}{l}\text { Panicle length } \\
\text { (cm) }\end{array}$ \\
\hline Control & 0 & 68.6 & 25.4 & 42.9 & 0.6 & 68.3 & 42 & 18.9 \\
\hline \multirow[t]{4}{*}{ Granular } & 5 & 51.6 & 22.7 & 31.9 & 0.7 & 54.6 & 38 & 14.2 \\
\hline & 10 & 34.4 & 20.4 & 20.9 & 1.0 & 41.3 & 32 & 9.6 \\
\hline & 20 & 24.9 & 17.9 & 14.8 & 1.2 & 32.7 & 39 & 5.6 \\
\hline & 40 & 22.6 & 20.6 & 15.4 & 1.3 & 36.0 & 33 & 4.3 \\
\hline \multirow[t]{4}{*}{ Liquid } & 5 & 51.4 & 26.8 & 29.1 & 0.9 & 55.8 & 43 & 14.4 \\
\hline & 10 & 44.8 & 21.1 & 24.8 & 0.9 & 45.9 & 45 & 12.8 \\
\hline & 20 & 35.0 & 17.4 & 19.7 & 0.9 & 37.1 & 42 & 10.4 \\
\hline & 40 & 30.5 & 25.7 & 18.6 & 1.5 & 44.2 & 40 & 7.4 \\
\hline \multicolumn{9}{|l|}{ Significance } \\
\hline Formulation & & $* *$ & $*$ & $* *$ & $* *$ & $* *$ & $* *$ & $* *$ \\
\hline \multicolumn{9}{|l|}{ Rate } \\
\hline Linear & & $* *$ & $*$ & $* *$ & $* *$ & ** & NS & ** \\
\hline Quadratic & & $* *$ & * & $* *$ & NS & $*$ & NS & ** \\
\hline Form. $x$ rate & & NS & * & NS & NS & NS & NS & NS \\
\hline
\end{tabular}

${ }^{2}$ Growth index $=[$ (height + width $1+$ width2)/3].

'Root : shoot ratio = (root dry weight/shoot dry weight).

${ }^{x}$ Plant biomass $=$ (root dry weight + shoot dry weight $)$.

**,*, ${ }^{\text {Ns }}$ Significant (eight replications) at $P \leq 0.01$ or 0.05 , or not significant at $\mathrm{P}>0.05$, respectively. 